\title{
AGRICULTURE AND ENVIRONMENT: INTERLINK WITH POVERTY DIMENSION
}

\author{
Ms. Naina Dhakal, MA, MPS ${ }^{11}$
}

\begin{abstract}
Despite of development efforts over decades 32 percent of the population is still below poverty line in Nepal. Economic, social, political and environmental factors are thought to be responsible for the poverty. Human effort to derive food for survival has direct and indirect impact on environment. Reducing poverty through income and employment generation is the focus of different development plans. There is interlinking between agricultural farming and environment. To reduce poverty and enhance environment each agricultural project which requires to produce assessment must be assessed economically too.
\end{abstract}

\section{Introduction}

The interrelation between the environment protection and economic development can lead to sustainable development. Despite of development efforts of the past years 32 percent of the population is below poverty line in Nepal (NLSS, 2003/04). This poverty is basically rural based and the source to subsistence livelihood in rural area is agriculture. It is also clear from the fact that around 65 percent of the population is depending in agricultural sector. Reducing poverty through income and employment generation is the focus of different development plans. It is supported by implementing different project and activities in agricultural sectors. There is interlinking between agricultural farming and environment. One system depends greatly upon the productivity of the others.

\section{Objective}

The objective of this paper is to find out interlink between agriculture and environment and to suggest for the lowering the environmental impact of agriculture on poverty.

\section{Dimensions of Poverty}

Poverty in Nepal has different dimensions as Human Poverty, Income Poverty, Social Exclusion and Empowerment. UNDP introduces the Human Poverty as lack of basic human capabilities such as literacy, malnutrition, shortened life span, poor maternal health and illness from preventable diseases. Income poverty refers to lack of income necessary to satisfy basic food needs usually defined on the basis of minimum calorie requirement (absolute poverty) and to satisfy essential non food needs such as for clothing, energy, as well as food needs ( relative poverty). Social inclusion and empowerment poverty are other dimensions. The consequences of inequalities in different qualitative dimension are social, political, cultural which occur when a group or community or even geographical region is excluded from social right to certain standard of living and participation into the decisions making process.

\footnotetext{
${ }^{11}$ Agricultural Economist, Gender Equity and Environment Division, Ministry of Agriculture and Cooperative, Singh Durbar, Kathmandu.

Email : nadhakal@moac.gov.np
} 


\section{Status of Poverty}

The first income poverty estimation was carried out on 1976/77 which estimated that 33 percent of the total population lives below poverty line. The next survey of 1984/85 estimated that 41.2 percent people live below poverty line. The survey done in rural areas in 1990/91 has estimated that high incidence of poverty falls hard on landless and small farmers. By development regions incidence of poverty in mid western and far western development regions are the highest (Tenth Plan, 2002). According to the living standard Survey, $1995 / 96$ and poverty rate in 1995/96 was estimated at 38.8 percent. Similarly for $2003 / 04$ it was estimated at 32.0 percent. In urban areas poverty rate in 1995/96 was 32.2 percent which dropped to 19.9 percent in 2003/04. Similarly for the rural areas it was 39.1 percent in 1995/96. It dropped to 32.5 percent in 2003/04.

Table 1: Trend of Poverty Situation in Nepal

\begin{tabular}{|l|l|l|l|}
\hline Fiscal Year & \multicolumn{3}{|l|}{ Percentage of population below poverty line } \\
\cline { 2 - 4 } & Rural & Urban & Nepal \\
\hline $\begin{array}{l}\text { Poverty Incidence in } \\
\text { 1976(SEIDCP, 1977) }\end{array}$ & 33.0 & 22.2 & 33.0 \\
\hline Poverty Incidence in 1995-96 & 39.1 & 32.2 & 38.8 \\
\hline Poverty Incidence in 2003-04 & 32.5 & 19.9 & 32.0 \\
\hline
\end{tabular}

Source: $C B S, 2006$

Based on the data NLSS, 1995/96, 95 percent of the poor people of Nepal live in the rural areas. Substantial disparities exist in the poverty incidence across the three major agro ecological zones. Such as Hilly Zone has highest poverty incidence followed by Mountains and the Terai. (CBS, 2006)

\section{Causes of Poverty}

Different studies have shown that poverty is caused by a number of factors such as economic, social, political and environmental (Hume, Moore and Shepherd, 2001, cited by Sharma, S)

\section{Economic Factors}

- Low productivity

- Lack of skills

- lacks of economic policies

- Economic shocks

- Terms of trade

- Technological backwardness

- Effect of Globalization

\section{Social Factor}

- Discrimination ( gender, ethnicity, cast )

- Poor health situation

- Inequality

- Lack of capital

- Culture of poverty 


\section{Political Factors}

- Bad Governance

- Insecurity

- Violent conflict

- Domination by regional/global superpowers

- Globalization

\section{Environmental}

- Low quality natural resources

- Environmental degradation

- Disasters (flood, drought, earthquake, etc)

- Remoteness and lack of access

- Propensity for disease

\section{Poverty and Agriculture}

Being an agricultural country, agriculture has dominant role to play in Nepal. About 65 percent of economically active population and 38 percent of the GDP is contributed by this sector (MOAC2005/2006). But vicious circle of poverty exists in Nepalese agriculture.

The low graded and least productive activities occupied by the poor and that too, in small patches and insufficient amount, subsistence agriculture and low capacity to invest to increase productivity due to low income level etc are the main causes of the vicious circle of poverty existing in agriculture sector. According to the NLSS 1995/96, the average farm size of holding for low income households was less than 1.0 hectare. The NLSS further indicates that land-ownership is the crucial factor determining poverty. Agriculture plays important role in the lives of rural population. A large majority of households depends upon agriculture and allied activities such as livestock-rearing and forest production collection.

Beside this, low economic growth, low social and economic infrastructure, a relatively high population growth, low access to non-agricultural income and deep -rooted cultural practices are the major causes of poverty in Nepal. Population growth rate of Nepal is 2.24 percent and population density is 157 persons per sq km (NPC, 2001 and CBS, 2006). The growing population of Nepal has competition for food. In the process of livelihood and comfortable life, human beings exert pressure on the environment. Degradation of environment through deforestation, soil erosion and landslides is already affecting significantly the livelihood of the poor people specially life of women and children.

\section{Environmental Impact}

Project environmental impact can be defined as any changes in the quantity and /or supply of an environmental good or services resulting from the project. These impacts can be of the following types

- Positive and negative impact

- On-site and off site impact

- Physical socioeconomic, and psychological impact

- Near -term and long term impact

- Internal and external impact 
Some of the environmental impact created by agricultural sector are as following:

\section{Deforestation}

The forests of Nepal which occupy 29 percent of the total landmass are a major natural resources. They supply about most of the fuel and fodder need of the rural areas. There is complex and symbiotic relationship between farms and forest. Simply, productivity of the one system depends greatly upon the productivity of others. Increasing number of mouth for food, extended cultivation on marginal land and steep slopes leading to deforestation, soil erosion and landslides. The degradation and deforestation has negative impact on environment which affect livelihood of household specially of women's life. Because women's are the ones who must walk far to collect fuel and fodder, adding hours to their already long work days. Hence less time is left to the agricultural activities.

Since the United Nation Conference on Environment Development Summit in Rio de Janeiro in 1992, has urged that poverty is a driver of land degradation and deforestation. Poor people have fewer assistance and options and less security (Deininger and Minten, 1996). Deininger and Minten further link poverty and deforestation through the presence and absence of alternative opportunities. They added that poor households degrade forest because of lower off farm opportunities due to fewer skills, family emergencies and less preference on environmental services.

Out of the total landmass of Nepal percentage of the forest has been dropped from 37.82 percent in 1986 to 29 percent in 2000 (CBS, 2006) Most of these forests have been cleared for agricultural purposes.

Table 2: Annual Deforestation by Ecological Belt

\begin{tabular}{|l|l|l|}
\hline Physiographic Zone & $\begin{array}{l}\text { Annual } \\
\text { Deforestation in 20 Terai } \\
\text { District }\end{array}$ & $\begin{array}{l}\text { Annual Rate of Forest Area } \\
\text { Decreased }\end{array}$ \\
\hline Mountain and Hills & 0.06 & 2.30 \\
Tarai & & 1.30 \\
\hline Nepal & & 1.70 \\
\hline
\end{tabular}

Source: CBS, 2006

\section{Degrading Soil Fertility}

To fulfill the need of growing population land has been over cultivated and overgrazed. To obtain higher productivity different fertilizers and plant protection materials are used. Use of nitrogenous fertilizer produces organic acid. Use of pesticide affects bee and other agricultural friendly living beings, which ultimately reduces pollination and soil protection. It reduces soil fertility and productivity of desirable plants.

\section{Soil Erosion}

Small holding has forced poor people for intensive cultivation, and cultivation of the steeply sloppy lands which lead to soil erosion and depletion of plant nutrients and moisture holding capacity. Agricultural production needs market. Construction of road linkage between rural and urban areas is the key to agricultural development. It can link between inputs and output flow between rural and urban markets. Road construction is also the cause of soil erosion including deforestation and landslides. 
Table 3: Estimated Soil Erosion Rate at Selected Site, Nepal

\begin{tabular}{|c|c|c|c|}
\hline Area & $\begin{array}{ll}\text { Location } & \text { and } \\
\text { Characteristics } & \end{array}$ & Level Use & $\begin{array}{l}\text { Erosion Rate } \\
\text { (tone/km2/yr.) }\end{array}$ \\
\hline Siwalik Rang & $\begin{array}{l}\text { Eastern } \text { Nepal, South } \\
\text { Aspect, Sand Stone Foot } \\
\text { Hills }\end{array}$ & Forest to Grazing & $780-3680$ \\
\hline \multirow[t]{3}{*}{$\begin{array}{l}\text { Middle } \\
\text { Mountain }\end{array}$} & $\begin{array}{l}\text { Far western Nepal, South } \\
\text { Aspect of Surkhet }\end{array}$ & $\begin{array}{l}\text { a. Degraded Land } \\
\text { b. Gully Land } \\
\text { c. Degraded, Heavily } \\
\text { Grazed gully Land }\end{array}$ & $\begin{array}{l}2000 \\
4000 \\
20000\end{array}$ \\
\hline & $\begin{array}{lr}\text { Central Nepal, Mahabharata } \\
\text { Lake, Steep } & \text { Slope, } \\
\text { Metamorphic } & \text { and } \\
\text { Sedimentary rocks } & \end{array}$ & $\begin{array}{ll}\text { a. Degraded, Forest } \\
\text { and Agriculture } \\
\text { Land } \\
\text { b. Gully Land }\end{array}$ & $\begin{array}{l}3150-14000 \\
6300-42000\end{array}$ \\
\hline & $\begin{array}{l}\text { Northern Foothills of } \\
\text { Kathmandu Valley }\end{array}$ & $\begin{array}{l}\text { a. Degraded, Forest and } \\
\text { Shrub Land } \\
\text { b. Over Grazed Shrub Land } \\
\text { c. Severe Gully Land } \\
\text { Dense Forest } \\
\text { a. Protected Pasture } \\
\text { b. Overgrazed Grass } \\
\text { c. Gully Overgrazed } \\
\text { Grass Land }\end{array}$ & $\begin{array}{l}2700-4500 \\
4300 \\
12500-57000\end{array}$ \\
\hline
\end{tabular}

Source : CBS, 2006

\section{Agricultural Drought}

Agricultural drought sets due to the soil moisture stress that leads to significant decline in crop yields. This effect leads to other consequences, secondary and territory, that has further impact an economy. For example, when agricultural production declines, food and other commodities tend to cost more and cause economic inflation in a society. Chain effects of persistent droughts can shatter whole of an economy. Agricultural droughts at a global scale can cause severe food shortage.

\section{Loss of Biodiversity}

Biodiversity has important role for the future crop improvement programs for human welfare. Disturbance of ecosystem, over-exploitation of animal and plant species, destruction of habitat are threatening biodiversity in Nepal. 


\section{Human Health Hazard}

Use, misuse and residue of pesticide is not only destroying the soil nutrient and agricultural friendly living things but also threatening present and future human health. Water pollution is increasing. Beside many other factors, agricultural waste and excessive use of agrochemicals such as fertilizers and pesticides are also responsible for water pollution. The environmental problem may cause Cancer and can shatter people's sense of security. The resulting fear can be emotionally debilitating and even financially devastating. It increases health care and lost productivity, lost agricultural crops and recreational opportunities (Davies, 1996)

\section{Water Pollution}

Sample studies of the Kathmandu valley water have been shown that the level of contamination is already higher than the WHO standards for human consumption. Due to the water pollution the major rivers of Kathmandu have been spoilt. Water from such rivers is not good even for irrigation purpose. How poverty is interlink with environmental degradation and reduction of productivity is shown in the following diagram-

\section{Interlink between poverty and environment}

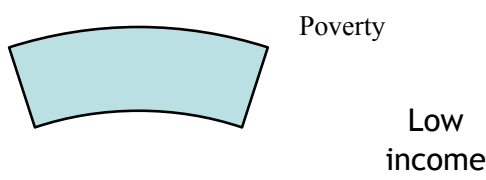

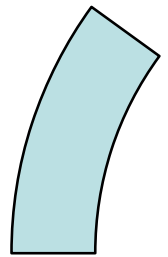

Decrease productivity income

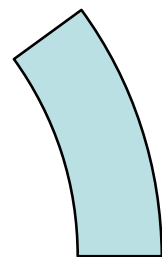

Exploitation of natural

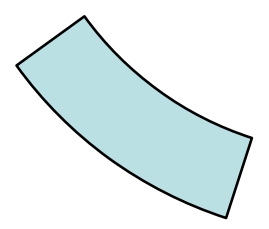

Environmental degradation

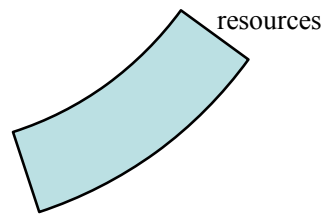

\section{Challenges}

Agricultural production including livestock rearing such as pig and poultry is environmentally sensitive. It is right to fulfill the basic need of every human being. In the process they exert pressure on the environment. As a result natural environment gets external stimulus and different kinds of impacts are generated.

The greatest challenge today is to build new Nepal that rejects current condition of poverty against unsustainable consumption and production behavior and give right prominence to the 
social, ethical, and human as well as the economic dimension of life of this future generation. Environment and poverty eradication factor are integrated in sustainable development policies, plan, program and action. Hence environment assessment is very essential. There is different aspect of environment assessment such as biological, physical and socio- economic.

\section{Economic Evaluation of Environmental Impact}

Economic evaluations are based on the project's costs and benefits to the economy as whole, measured in economic values. These evaluations examine all of a project's impacts, including its environmental consequences (ADB, 1998). Following are the three types of analysis:

- Quantitative

- Semi quantitative

- Qualitative

In economic evaluation, the magnitude of each impact is converted from physical units to monetary units. Evaluation process is as following:

- Impacts identification and screening The project's actual and potential impacts is identified and screened.

- Environmental valuation

The most important impacts are quantified and assigned monetary values to prepare them for economic evaluation.

- Incorporated the project economic analysis.

In the last the results of the economic evaluation are incorporated into the project economic analysis.

\section{Attempt for Poverty Reduction and Environment}

Poverty reduction has been the major concern of Nepal since long time - Increasing agricultural production, thereby increasing income of the poor farmers is its main priority. Nepal has implemented twenty years Agriculture Perspective Plan (APP, 1995) with a view to develop overall economy and alleviating poverty through development of agriculture sector as a whole. The Review of Ninth Plan estimated that the people living under poverty line were brought down to 38 percent from 42 percent (NPC, 2002).

Tenth Plan has set poverty reduction as the only objective of the whole plan. Target was fixed to bring down the percentage of people living under poverty line to 30 percent by the end of Tenth Plan (2002-2007). Similarly it has aimed to direct towards the proper management and utilization of natural resources and the achievement of sustainability in its use by involving all concerned stakeholders in the management of environment and the natural resources. Hence it has objective as interrelation between the environment protection and the economic development can lead to sustainable development; emphasis will be given to the protection of natural environment protection, restoration, and sensible use of resources. (Tenth Plan, 2002 )

According to the Tenth Plan:

- If the environment is protected, the gross domestic production will be increase and the sustainable development can be achieved.

- Environment protection will assist in the poverty alleviation and improved environmental health will also significantly contribute to the human resource development. 


\section{Regulatory Process}

To protect environment Nepal has already brought an Environment Protection Act and Rule 1997 has stated that the proponent must furnish an environment impact evaluation and must submit a report along with the proposed project. Agricultural project proposals that require Environmental Impact Assessment (MOPE, 1997) are:

1. Clearing of forests covering more than 1 hectare in the hills and 5 hectares in the Terai and using them for agricultural purposes.

2. Following activities relating to construction:

a. Construction of more than 5 kilometers long agricultural roads.

b. Construction activities for farming more than 5000 domestic fowl.

c. Construction activities for farming more than 500 cattle.

d. Construction activities for farming more than 5000 small livestock (sheep, goats, and pigs).

e. Urbanization plan in cultivable lands.

3. Following activities relating to toxic substances (Only the listed one):

a. Import of more than 10 tons of a toxic substance.

b. Sale, supply, storage and disposal of more than 1 ton of a toxic substance.

c. Use of 1 ton of a toxic substance in a single area.

d. Activities relating to insecticide plants or toxic substances.

\section{Implementation Status}

APP has also emphasized the three dominant national concerns: eliminating poverty, enhancing natural environment and improving the condition of women. It has emphasized that the packaging of the priority inputs will require EIA if the commercial pocket is large. Beside this it has also specified the implementation of the Integrated Pest Management (IPM) Approach. Due to the IPM approach even in the small level environmental assessment is applying directly on the farm.

Nepal has great challenge to compete with the world market. Although environmental rules and act has been passed it has not completely implementing in all the aspects. Some of the activities are still beyond the control of laws. It is due to the lack of clear implementing mechanism, monitoring and reward and punishment system. Similarly some of the rules are not specific.

\section{Conclusions and Recommendation}

Poverty, agriculture and environment have interlinking relationships. Reducing poverty is supported by implementing different project and activities in agricultural sector. It produces impact on environment. One system depends greatly upon the productivity of the others and if one system is damaged another sector has greater impact. So it is required to balance both the sectors. Even though different policies and Act has been formulating in practice different problems are associated with implementation. The gap between principle and practice should be overcome. Hence to lower environment impact, every project associated with agriculture and poverty must be analyzed properly taking account of the social and economic dimensions. 


\section{REFERENCE}

1. ADB, 1998: Economic Evaluation of Environment Impacts, Office of Environment and Social Development, Manila, Philippines.

2. CBS, 2006: Nepal Living Standards Survey (1995/96 and 2003/04), Kathmandu:

3. CBS, 2006: Environment Statistics of Nepal, Kathmandu.

4. CDE, 2004: Nepalese Economy Towards Building a Strong Economic Nation-State, $T U$ and NHBS, Kathmandu

5. Davies, de J. Clarance, 1996: Comparing Environmental Risk Tools for Setting Government Priorities.

6. Deininger, K.W and Minten, B, 1996: Poverty Policies and deforestation: The Case of Mexico "PEG Working Paper, The World Bank.

7. MOAC, 2005/06: Statistical Information of Nepalese Agriculture, GON, Kathmandu.

8. MOAC, 2002: Agriculture And Environment, GON, Kathmandu.

9. NPC, 2002: Tenth Plan, Kathmandu.

10. Sharma, S, 2005: "Chronic VS Transient Poverty in Nepal: Need for Quantitative Analysis " A Journal of Administration, Management and Development Vol.8 No.2

11. UNFAA, 2002: Population, Environment and Poverty Eradication for Sustainable Development, Action Toward Johannesburg 2002, Background Paper No. 14 